http://dx.doi.org/10.18778/0208-6107.31.09

\author{
Anna Wołczyńska \\ Akademia Górniczo-Hutnicza \\ im. Stanisława Staszica w Krakowie \\ magadalema@o2.pl
}

\title{
HUMAN DRAMA IN ART OF THE BLIND PAINTERS SARGY MANN AND JOHN BRAMBLITT, AND IN FR. JÓZEF TISCHNER'S REFLECTIONS
}

\begin{abstract}
Nothing intrigues more than performing tasks that disability renders impossible. Overcoming physical limitations and mental restraints raises an interesting issue of the human creative potential broadly investigated by scientists and acutely experienced by the disabled. A cruel disease that leads to complete blindness appears even more dramatic when affects visual artists. A blind artist painter sounds an oxymoron, but the stories of Sargy Mann and John Bramblitt prove that a human being can always defy comfortable schemes. A sighted observer may be puzzled by complexity of this multipolar drama marked with painful turning points, but also, perhaps surprisingly, with a feeling of gain, sense, and reward. The artists' personal and subjective perception of the loss inspires a discussion that presents universal values in a broader perspective. Beauty and truth, uncertainty and courage are to be found in the narrations of the artists above and the essays of a distinguished Polish philosopher Fr. Józef Tischner. The article portrays the silhouettes of the blind painters focusing on their artistic strive to a meaningful and rewarding life in the light of philosophical reflections based on the axiomatic concepts of beauty and truth
\end{abstract}

\section{Keywords:}

blindness, painting, philosophical values: beauty and truth

\section{INTRODUCTION}

Human existence carries a stigma of multifaceted drama. With a human being as its central protagonist, the drama may develop both within the intrinsic world of a complex human psyche and at the borderline of multiple and inevitable interactions with the external environment. Exposed to recurrent trial, effort and doubt, the man has to take the role of an active doer rather than a passive 
recipient. Whether in happy and successful moments or in the episodes of failure and loss, life demands action.

Surely, one of the most trying experiences is an incurable disease which ruthlessly revolts existential foundations. Confronted with the unknown, the afflicted individual has no choice but to face the truth about his physical and mental condition as well as about the surrounding reality which no longer is familiar and comfortable. Losing the eyesight is a devastating trauma for all who experience total blindness, but it is even more dramatic for a visual artist who thus loses his basic work-tool. For him, facing the truth calls for more effort in re-orienting the existential fundamentals and a sense of grounding.

The paradigm of truth is one of the basic philosophical issues. A distinguished Polish philosopher Friar Józef Tischner (1931-2000) calls it "the key value" as the truth is a "gateway for our ties with the surrounding world." Even more, the truth is vital for a human being who cannot realize his potential basing on false assumptions. Any deviations in the truth domain and true experiencing the world result in ineffective, mistaken or improper realization of superior values. ${ }^{2}$ Tischner's works from the years 1966-1975 reveal same consistent approach. In his philosophical essays Tischner states that "truth is the key to the world" arguing that only cognizance in harmony with the reality is true. ${ }^{3}$ The example of two blind artists, Sargy Mann and John Bramblitt, show that the man, however ill-fated and suffering, can successfully fulfil the conditions denoted by Tischner's definition of truth: consistency of thought and reality, consonance of emotion and value, and finally accord between the man and himself. ${ }^{4}$ Tischner also defines the central protagonist of the title drama stating that being a man invariably means "the ability to go beyond oneself, $[\ldots]$ first detaching from oneself, rising above, and suddenly regaining oneself before oneself." " Tischner's concept of drama assumes an interaction between the central protagonist and his self as well as the other people. Thus the man remains in a continuous and truth-revealing dialogue with himself and with the others. ${ }^{6}$ Mann's and Bramblitt's cases analyzed more thoroughly below exemplify this thought-provoking declaration.

\footnotetext{
${ }^{1}$ Józef Tischner, Krótki przewodnik po życiu (Kraków: Wydawnictwo Znak, 2017), 108. All quotes from the writings of Fr. J. Tischner in the author's translation.

${ }^{2}$ Ibid., 108-109.

${ }^{3}$ Józef Tischner, Świat ludzkiej nadziei. Wybór szkiców filozoficznych 1966-1975 (Kraków: Wydawnictwo Znak, 1992), 64-65.

${ }^{4}$ Ibid., 107.

${ }^{5}$ Ibid., 13.

${ }^{6}$ Dobrosław Kot, "Przyswoić sobie siebie i ziemię. Uwagi o Tischnerowskiej filozofii dramatu," Ethos, no. 1-2 (2007): 255-260.
} 


\section{DRAMA OF ART AND TRUTH}

Blind persons' art inevitably raises the question of the extent in which eyesight determines creative potential of an individual and the constraints that blindness imposes. How come, a totally blind person successfully creates masterpieces of visual art? Even more, he cultivates color painting which finds recognition among the critics and the purchasers! How does he match colors and control the process of creating a picture?

Sargy Mann, a blind British artist painter (1937-2015), explains this matter in the following way:

Reasonably enough, people always want to know how I arrive at the color in my paintings when I can't see at all. It is worth mentioning here that most people, I think, dream in full and perfect color. I certainly do, and when one is asleep one is perceptually blind, so the brain can do it - though God knows how. I can imagine color and color combinations pretty well. [...] In the paintings I have made since losing all my sight, which is to say the last 10 years, I cover the whole canvas from my imaginings, and my knowledge of my pigments and how they look in different combinations.

Sargy Mann won an artistic and commercial success. Surely, not without meaning was his education gained in Camberwell College of Arts where for almost 20 years he taught painting and specialized in the transforming abilities of light and color. Artistic studies, his own professional practice and then teaching experience doubtlessly strengthened his understanding of the matter sufficiently enough to adopt the palette of colors in a totally sightless and partially intuitive way. An indubitable support came from his wife Frances Carey, also an artist, whose contribution in creating the paintings did not restrain itself to auxiliary works and calibration of silhouettes' measurements on the canvas. Frances had a say in color matching and thus a substantial influence on the final form of her husband's works. Mann explains how this cooperation worked:

As the painting proceeds, and as a result of much discussion, Frances begins to mix up colors for me, and both the color and the drawing change and develop, often very dramatically. ${ }^{8}$

Artistic crux finds its reflection not only in the process of color matching, sketch taking, and paint spreading. The artist's creative urge reflects itself in the fundamental philosophical inquiries, all the stronger in the case of a blind painter. Like in a lens, in the artist-audience bond fundamental human dilemmas

\footnotetext{
${ }^{7}$ Sargy Mann, "Sargy Mann: How a Blind Painter Sees," BBC News Magazine (14 June 2015), https://www.bbc.com/news/magazine-33109430.

${ }^{8}$ Ibid.
} 
emerge and the primary philosophical concepts co-occur. In response to the basic philosophical investigation on the entity of a human being, Tischner gives a straight reply: the man is a dramatic persona. It is because the man participates in a drama, which means he both creates a drama and by a drama he is being created. ${ }^{9}$ Tischner emphasizes the corporal aspect of human existential drama, the aspect often overlooked or underestimated by other philosophers. "Dialogic corporal dimension has escaped philosophers' attention," he says. ${ }^{10}$ Tischner points out that it is corporality which opens the perspective for a dialogue: "But for the body, a dialogue would not be possible."11 Art, with the human corporality so emblematic, forms the ground not only for a concept of drama, but also a dialogue. Universally true for all human mankind, the art and dialogue become even more revealing when they involve individuals confronting their existence marked by a personal tragedy and disability.

In his essay "Thinking in the Beauty Element", Tischner enters into discussion with other philosophers, Friedrich Nietzsche and Martin Heidegger, stating that truth, beauty and goodness are expressions of the human drama and transcendental values nonetheless. These values impose the criterion of superiority and inferiority, rise and decline, as well as a hierarchical order. Along with time-bound, linear experiencing the events, human existence acquires the stigma of a drama whose subject is contention about superior and inferior values, primary and secondary ones. He says that the basic system of truth, beauty and goodness constitutes a dramatic disposition which features an uneasy strive for unity. This strive entails dispute on priority and authenticity. Tischner poses a question: which is superior: beauty or goodness, beauty or truth, truth or goodness? Which should be the priority for the man as a dramatic hero? ${ }^{12}$

Analyzing Sargy Mann's and John Bramblitt's artistic endeavors one can risk a statement that truth was for them the first and foremost paradigm. Quest for truth pushed the blind painter Sargy Mann to pick his brushes after the return from hospital where, after long and unsuccessful treatment, he had been registered totally blind. He recalls:

I took a canvas, a plastic chair and my painting trolley out into the sunny garden, chose from my memory one of the subjects, felt the canvas, imagining as intensely as I could, and I thought: Here goes. I put ultramarine on a brush and started painting the top right hand corner of the canvas and I saw it go blue. It wasn't memory, it was a percept." 13

\footnotetext{
9 Józef Tischner, "Zarys filozofii człowieka dla duszpasterzy i artystów," in Józef Tischner, Myślenie w żywiole piękna (Kraków: Wydawnictwo Znak, 2004), 139.

${ }^{10}$ Józef Tischner, Spór o istnienie czlowieka (Kraków: Wydawnictwo Znak, 1998), 104.

${ }^{11}$ Ibid.

12 Ibid., 22.

${ }^{13}$ Mann.
} 
This percept led Mann to the conviction that "there is painting after blindness" ${ }^{\prime 14}$ and, eventually, to a fulfilling continuation of his artistic career. It was quest for truth that pushed John Bramblitt, a young American blind man struggling with severe epilepsy and depression, to an artists' shop to buy paints. In his fascinating book "Shouting in the Dark - My Journey Back to the Light" he describes the day when with help of a shop assistant he was discovering various pigments, trying their textures, and learning a haptic way to feel the differences in color. He was lucky to be assisted by the shop assistant completely undisturbed by the fact that a blind person wanted to paint, patiently and naturally serving all needed information and useful advice. In these words Bramblitt describes the day he became a painter: "I knew now that this was what I was going to do. [...] I went to a store as a blind man and came out as an artist." 15

Though completely divergent as far as formal education is concerned, Mann's and Bramlitt's artistic paths have one major point of osculation: courage to face the uncertainty in order to face the truth. Bramblitt puts it this way:

My thoughts had a kind of twisted logic, even if they did rest on the doubtful foundation that a blind man could paint, but I decided to accept the challenge of this premise. ${ }^{16}$

A nevertheless dramatic choice also for Mann who with a self-examining reflection pondered on painting with total blindness, a seeming nonsense and a reasonable conviction disturbed by a nagging assumption: "What would happen if I gave it a go? What's to lose?" on human strive for truth and his hypothetical question: Granted, we will truth: why not untruth instead? And uncertainty? Even ignorance?" 18 Discussing Nietzsche's views, Tischner explains that there is no truth in entity that hides behind expression. Entity is an illusion, more or less a long-lived fallacy - imitation of a substantial being, or a material rather. Colors, shapes, objects, but also human dramas, pose the material condition which implies creation and a pieceof-art state. Truth and falseness, good and evil, despair and delight are the material for an artful masterpiece which must be processed according to the beauty ideal. Beauty is a reliable value, Tischner states. Even more, he says, the sense of human existence lies in the artistic creativity ${ }^{19}-$ and it is hard to reject this

\footnotetext{
${ }^{14}$ Ibid.

${ }^{15}$ John Bramblitt, and Lindsey Tate, Shouting in the Dark. My Journey Back to the Light (Guilford Connecticut: Lyons Press, 2012), 102-5.

${ }^{16}$ Ibid., 105.

17 "Blind Painter Sargy Mann: Painting with Inner Vision," YouTube video, 4:29, posted by BBC News, October 26, 2014, https://www.youtube.com/watch?v=x9vHwCIaSwM.

18 Friedrich Nietzsche, Beyond Good and Evil, trans. Marion Faber (New York-Oxford: Oxford University Press, 2008), 5.

19 Tischner, Myślenie w żywiole, 9-10.
} 
thesis as too daring. Having found out that "there is painting after blindness", Mann and Bramblitt had to open a new chapter in the existential drama: to explore their intrinsic spiritual world and bring it to life through artistic media.

\section{NO BEAUTY BEYOND THE TRUTH - HEIDEGGER}

The realistic resemblance to a portrayed person or an object seems a fundamental issue for most artists. This proved true also for Mann, educated and matured in the tradition of realistic painting. However, due to his total blindness, he had to modify his atelier and technique, but even more the cognitive process of creating pictures whose basis was now memory and imagination. He states: "If your subject is your own experience, then as long as you have experience you have a subject." ${ }^{20}$

In a similar tone Bramblitt explains his self-retrospection:

Many of them [images in my mind] were memories of my past, images that I loved from my sighted life, and I lived in fear of them disappearing one day $[\ldots]$ and leaving me with nothing. [...] I wanted to get these memories down on paper to keep them forever. ${ }^{21}$

This finds reflection in Heidegger's views. He says that what keeps us in our being maintains us as long as we ourselves maintain what maintains us. We retain it if we do not extricate it from our memory. "Memory is the gathering of thought," Heidegger states ${ }^{22}$ and then he expands his thought by analyzing the concept of mental representations. He says that by presenting an object, for instance a sculpture or a text, we employ its representation. But where are these representations? - he wonders - We have them in our minds. Our consciousness. Our souls. Representations are in our intrinsic world, heart of hearts, that is objects' representations.”23 Sargy Mann puts it this way: „Painting is a visual metaphor for my experiencing the reality" 24 , and further "a device for preserving an experience from oblivion." 25 Tischner, on the other hand, states:

\footnotetext{
20 "Blind Painter."

${ }^{21}$ Bramblitt, and Tate, 105.

${ }^{22}$ Martin Heidegger, What is Called Thinking?, trans. Fred D. Wieck and J. Glenn Gray (New York-Evanston-London: Harper \& Row Publishers, 1968), 3. See also Tischner, Myślenie w żywiole piękna, 12.

${ }^{23}$ Ibid.

24 "Blind Painter."

${ }^{25}$ Tim Adams, "Sargy Mann: the Blind Painter of Peckham," The Guardian (November 21, 2010), https://www.theguardian.com/artanddesign/2010/nov/21/sargy-mann-blind-painter-tim-adams.
} 
The body is a nest for experience. Experience denotes the man encountering the outer reality. To express the abundance of experiences one needs a language of art, poetry, religion. ${ }^{26}$

Both Mann and Bramblitt based their artistic pursuit on their memories and experience. They strived for truth in their productions through "haptic visualization," the transfer of the haptic stimuli into visual imagining. Bramblitt explains the method:

It is a process of breaking into small parts the object you want to visualize. In this way you can gather careful detail that relates directly to every other part. [...] I feel each small part until it is crystal clear in my mind, and then I feel the whole until it all gels together perfectly. [...] I approached the problem from an artist's viewpoint as artists deconstruct an image and then put it back together all the time. ${ }^{27}$

A corresponding approach can be found in Mann's narration:

It seemed as if my brain was taking tactile information about relative positions in space, and using it in essentially the same way as I had previously used visual information, in order to build up a coherent understanding from the position of my eyes. [...] Working out the three-dimensional into two-dimensional geometry of the imagine space and directional sunlight was very challenging and stimulating and called on mathematical parts of my brain that had remained pretty dormant since the late 50 's. ${ }^{28}$

Armed not only with a sense of humor but also some battens and a cardboard tube for measuring distances, Mann defines his tactile method as a "bridging the gap between painting and sculpture" 29 stating that "experience starts with touch." 30

Tischner agrees with Heidegger that loss and lack can be more vitally important for the man than the tangible reality he experiences. In Heidegger's terms "What is thought-provoking, what gives us to think, is not anything that we determine, not anything that only we are instituting, only we are proposing. [...] what of itself gives us most to think about, what is most thought-provoking, is thisthat we are still not thinking. This now means: have still not come face to face." 31 According to Tischner: "This which turns away may be of bigger importance

${ }^{26}$ Józef Tischner, "Cielesność w horyzoncie piękna," in Józef Tischner, Myślenie w żywiole piękna (Kraków: Wydawnictwo Znak, 2004), 220.

${ }^{27}$ Bramblitt, and Tate, 144.

${ }^{28}$ Mann.

29 Charles Darwent, “Sargy Mann obituary," The Guardian (April 16, 2015), https://www.theguardian.com/artanddesign/2015/apr/16/sargy-mann.

30 "Blind Painter."

${ }^{31}$ Heidegger, 6. 
and consideration for a man than this which shows itself, touches and concerns." ${ }^{32}$ Such paradox is to be noticed in the both painters' endeavors. Along with definite losing the sight, Mann changed his artistic emploi turning from landscape painting into portrait and figurative pictures. As he explains this surprising change of heart, painting people became more important as he could not see them anymore. "I suppose - he says - you always paint the things you most want to see." ${ }^{33}$ And he also adds: "As I got blind, getting figures and distances became more important." ${ }^{34}$

Adaptive techniques applied by Mann did not include the spacious relations only. In the consequence of the disease and disability he got liberated from restrictions imposed by realism and embarked on ultimate artistic freedom. By paradox, now the color made the value of works. Mann says:

Because I was not receiving any visual information about the color and light, I simply painted things the color I knew them to be. ${ }^{\prime 35}$ Or he wanted them to be. He explains: "I chose my colors much more intuitively and with much more overtly decorative way which, before, I would have never allowed myself to do. It seems that blindness has given me more freedom to use color in ways that I would not have dared to when I could see. ${ }^{36}$

An identical feeling of freedom observes Bramblitt:

When I first started painting, I tried to keep things realistic. But now I don't. If I see a purple cow in my mind, or a woman with blue skin, then that's how they end up in my painting. ${ }^{37}$

Liberation from a real-color depiction led both artists to the original, personalized, and highly appreciated style, which consequently evoked a powerful and emotional reception by the audience .

They are not cozy little conventional paintings. They are edgy dangerous, they tell us stories, they are full of impact through the color. I think they are very individual, it's a sensation and he's brilliant ${ }^{38}$.

- says the curator of Mann's exhibition, while one of his avid fans adds: "There is a freedom in his work, which only one with a supreme mastery of struc-

\footnotetext{
32 Tischner, Myślenie w żywiole, 11.

${ }^{33}$ Adams.

34 "Blind Painter."

${ }^{35}$ Mann.

36 Sargy Mann, documentary film directed by Peter Mann, 38:30, 2006, United Kingdom, produced by Peter Mann Pictures, https://www.youtube.com/watch?v=8x6c2W_nGNA.

${ }^{37}$ Bramblitt, and Tate, 174.

38 "Blind Painter."
} 
ture, light and color could ever afford." ${ }^{39}$ Bramlitt's work has received same applause. "John's talent for creating emotion through his use of color and texture in his paintings is evident. He successfully challenges people's conceptions of blindness, ${ }^{40}$ reads Governor Rick Perry on the cover of the book. Sold in more than 20 countries, Bramblitt's paintings win critics' respect and viewers' admiration. Would just aesthetic value count for so much?

\section{ALL TRUTH IS IN BEAUTY - NIETZSCHE}

"Our highest dignity lies in the meaning of works of art," $" 41$ Tischner quotes and explains Nietzsche's views on the axiomatic values in discussion. The German philosopher gives an absolute priority to beauty. Goodness is goodness if it is beauty at the same time, truth is truth as long as it is a beautiful truth. Existence, goodness and truth reach their absolute justification in beauty, while aesthetics is the only reliable metaphysics. ${ }^{42}$ Also Tischner is inclined to claim the superiority of beauty, although he believes beauty naturally refers to truth. Beauty as a philosophical paradigm holds an ominous power to grasp the world in, out and through. Tischner poses a question: "Does it mean that a beautiful illusion is no longer an illusion but the ultimate truth of beauty?" If so, he wonders, each artifact would be a self-contained, autonomous world with no connections with the real world. ${ }^{43}$ Whichever value wins priority, both seem to work for Mann and Bramlitt.

"An aesthetically mesmerized sighted viewer is intrigued by unaccustomed color juxtapositions," says prof. Semir Zeki from University college London. ${ }^{44}$ Indeed, Mann's paintings emanate with vibrant colors and the original palette of strong and saturated dyes often cross-linked with pastel tones. A careful viewer can easily trace brush strokes which introduce colorful patches that intermingle with one another through the layers. Rubbed with finger tips, paints give a desired effect of watercolors and consequently the impression of light and translucence. The visible contrast between a solid patch of a definite color and infiltrating tones builds up an intrinsic energy of Mann's painting. Despite the silhouettes depicted in a sketch-like manner whose contours often sunk into the background, in an astonishingly poignant and convincing way the artist conveys the motion and atmosphere. His works are filled with a huge load of emotions

\footnotetext{
${ }^{39}$ Sargy Mann.

${ }^{40}$ Bramblitt, and Tate, the book's cover.

${ }^{41}$ Friedrich Nietzsche, The Birth of Tragedy out of the Spirit of Music, trans. Shaun Whiteside (London: Penguin Books, 1993), 5. See also: Tischner, Myślenie w żywiole piękna, 22.

${ }^{42}$ Ibid.

${ }^{43}$ Ibid., 22-23.

${ }^{44}$ Adams.
} 
which does not leave the viewer indifferent and make him emotionally engaged in interpreting the pictures.

The color choice and the free-hand paint spreading implies associations with impressionists who were Mann's powerful inspiration along Pierre Bonnard's art, the most recognized Nabi representative. In "Three Figures By the Sea", however, the whole composition, the arrangement of characters against the architectural elements may provoke associations with the works of Italian Renaissance classics (Botticelli, Rafael), or the Dutch or German romantic period due to the motif of rooms with open doors and windows (Johannes Vermeer, A sleeping girl; Peter de Hooch, A courtyard in Delft; Caspar David Friedrich, $A$ woman by the window). The "silent" presence of human figures inevitably leads a viewer to Edward Hopper's works whose alienated characters, as if hardened still in their actions, provoke questions about their mutual relations. It is hard to resist the impression of psychological depth of a Proustlike painter's narration performed by Mann. Beyond any doubt, he was an exceptionally keen observer of the surrounding world with his artistic sensitivity, like a radar, faultlessly detecting human emotions.

A similar experience awaits the viewer of Bramblitt's Pops Carter portrait, his first picture sold. The painting came to liking both of the buyer and the model.It may please any sensitive art admirer just as well. The model, a musician and a middle-aged man of the Afro-American origin, is presented against the black background from which comes out the cowboy hat and the man's face with grey whiskers and the glasses. Carefully put patches of soft but saturated colorsrender the model's features presented in a moment of meditation. The viewer's attention is drawn by the images and reflections on the glasses' panes, impalpable as they are. This not only proves the artist's visual memory but, above all, his incredible talent and intuition which helped Bramblitt create a picture precise and expressive in delivery, emotional and intriguing in reception. Many of his works explode with vibrant crazy colors, but just as many surprise with a subtle and sophisticated palette. It seems that the artist does not always employ colors in a way that the viewer finds unbelievable. Thus he keeps the technique and the content matter in a reasonable and productive equilibrium. "Painting crazy, smeared abstracts wouldn't help me cross the bridge into the sighted world," Bramblitt says. ${ }^{45}$ The same principle is to be found in Mann's paintings - freedom of artistic expression kept within the limits of cognitive understanding.

${ }^{45}$ Bramblitt, and Tate, 109. 


\section{BEAUTY JUSTIFIES TRUTH - TISCHNER}

Tischner bases his essay on Nietzsche's and Heidegger's postulations of beauty and truth in art. On one hand, Nietzsche says truth is truth as long as it may serve as a constructive element for a piece of art. On the other, Heidegger claims that an artifact is an artifact as long as it contributes to truth-being. Tischner says, they are both mistaken. In experiencing beauty the evaluation criterion is apparently beauty. Beauty unveils, but in a different way than truth. It uncovers by providing a justification or by depriving it. He claims that beauty justifies by uncovering, thus revealing some kind of truth. Truth is something more than a constructive element - it is also a goal. This proves the assumption that beauty also serves in uncovering and justifying the truth. Tischner continues by saying that the main point here is not to define the subtle relations between beauty and truth, neither to estimate the value of a given masterpiece. It is about a supreme sense of human drama. A piece of art is not to be "watched," Tischner states. It is to be experienced through presenting its drama to a viewer and through the viewer's participating in the drama that the artifact offers. ${ }^{46}$

Some kind of paradox unveils here. A severe visual impairment classified as blindness triggers a liberating "inner vision." Mann and Bramblitt defied their disability and thus proved a theoretically unavailable competence and skill. The state of absolute artistic freedom finds its embodiment in a highly individual, sometimes surprising or even puzzling color application. The color distortion leads, in turn, to an effective expression of truth in the content matter perceived by the sighted audience. Apparently, abstract and fantastic representations can reveal truth even better than disciplined and reality-faithful productions. Heidegger states that correct and fair is a representation which is apt to its object. "Rightness of representation has ever since been attributed to truth, that means the content of truth is defined on the basis of representation's correctness." ${ }^{47}$ Is it a Plato's cave effect where the real world turns out an illusion only? Or the effect of viewers' projections provoked by the paintings? "The world of beauty, so to speak the world of art, can be the world more real and true than any other world," ${ }^{48}$ Tischner says and then he adds: "The artist's job does not lie in providing people with too easy comforts. ${ }^{29}$ Nietzsche, on the other hand, observes that individual and subjective perception of reality never renders it true. By interpreting the obtained visual stimuli a man creates his reality and distorts it at the same time. A man thus becomes a trickster, or...an

\footnotetext{
${ }^{46}$ Tischner, Myślenie w żywiole, 14-15.

${ }^{47}$ Heidegger, 27.

48 Józef Tischner, Dramat wartości, in Józef Tischner, Myślenie w żywiole piękna (Kraków: Wydawnictwo Znak, 2004), 24.

${ }^{49}$ Tischner, Przyczynek do teorii podwójnego życia, in Józef Tischner, Myślenie w żywiole piękna (Kraków: Wydawnictwo Znak, 2004), 109.
} 
artist. As Nietzsche says - somewhat provocatively - "we are artists much more than we realize." ${ }^{50}$ Whether for a creator or recipient, an effective mixture of the familiar and recognizable with the puzzling and undefined definitely draws attention. The most successful works of art evoke and combine aesthetic evaluation along with the mental effort. Solving the puzzle hidden in the artifact, unraveling the artist's message helps to discover the truth about oneself. The viewer seeks in art the reflection of his entity and his self. Painting is probably the best mirror for humanity though made of canvas, not the glass.

\section{TRUTH AND BEAUTY - NOT CONTENTION BUT COEXISTANCE}

Tischner says that the fundamental philosophical paradigms, beauty, truth and goodness remain in conflict whose axis is priority. Yet, confronted with a multilayered reality, one observes a dynamic coexistence rather than antagonism. Time-bound, progressively experienced emotions automatically adopt a linear structure and confer the transcendental values their due importance. Tischner does not prioritize these values when he tries to define the ,selfness." "What is my self?" he asks. "What is self? Thanks to what Me is really Me?" he wonders, and then attempts to unravel the dilemma. One of the options is an assumption that $\mathrm{Me}$ is myself in the beauty that it embodies. Another possibility lies in the supposition that $\mathrm{Me}$ is myself in the reasoning thanks to which it opens onto the truth. A different perspective appears when behind the opening horizon there is goodness. Not passing any judgements on the three values, Tischner notices that searching for "selfness" is a game between the person and himself as well as between himself and others. The game, he says, happens in a drama and through a drama. ${ }^{51}$

A complete and incurable loss of eyesight is a turning point for a painter no matter how theoretically prepared, practically experienced and socially supported he is. It is a drama. He needs to redefine his attitude towards the artistic activity, the crisis which affected him and himself as a creative subject. For Sargy Mann visual impairment turned out not a barrier as much as a field for self-introspection and analysis. In addition to this, it worked as a trigger for a new technique and a turning point in the artistic carrier. John Bramblitt's artistic path was not so well grounded. His passion resulted rather from enormous physical and mental strains connected with a severe epilepsy and depression. It was a remedy for solitude and alienation, a way to express his fury, fear and frustration. Last but not the least, painting was a method to rediscover himself and his stand in life. "I'd buy these three oil paints and

\footnotetext{
${ }^{50}$ Nietzsche, Beyond Good, 81.

51 Józef Tischner, "Idea osoby," in Józef Tischner, Myślenie w żywiole piękna (Kraków: Wydawnictwo Znak, 2004), 161-2.
} 
a bunch of canvases and with them I'd paint my way back into the world." 52 How much determination and hope this sentence voices! A nearly 70-years' old Mann comments his situation in a more stoic manner:

Of course, I would never have chosen to become a blind painter but I have been thrilled to discover that I can make paintings without sight, and that this activity is far more like a continuation of my painting experience than I could possibly have imagined.

And he adds: "I had to reinvent the painting for myself." ${ }^{33}$ Regardless of emotions expressed, both painters proved experimental curiosity and a technical bravado to paint the world they could not see any more! Courage to challenge the doubts and to confront the truth - a risk greater than any others ${ }^{54}$ - liberated them from the fetters of disability without its suppression.

To quote Tischner: "Life is an act, and the act is an incessant extricating oneself from nonentity and nothingness. ${ }^{, 55}$ When striving for beauty and truth, he says, the man embarks on the path leading to self-regaining, a drama with no secure and definite happy end. The strive for self-regaining aims at selfsalvation. To salve oneself means to validate something in oneself and at the same time to defy something. ${ }^{56}$ Mann and Bramblitt passed the test. Not only did they get out of darkness of a personal tragedy, but also salved themselves by regaining the subjectivity and by discovering new horizons. For Mann it was a continuation of his artistic carrier, even more successful than before, for Bramblitt a start into an independent, meaningful and fulfilling life. Tischner says:

Life is creation in its matter. Creation of life is based on the incessant outgrowing of the presence over the past. Creation is freedom at the same time. Freedom occurs always when a liberated being surpasses the existing living conditions and establishes some new conditions for himself. ${ }^{57}$

This definition echoes the earlier one in which Tischner presents a man as a creator of positive values:

\footnotetext{
${ }^{52}$ Bramblitt, and Tate, 102-5.

${ }^{53}$ Mann.

${ }^{54}$ Cf. Nietzsche, Beyond Good, 8-9.

55 Tischner, "Dążenie do ontologizacji osoby," in Józef Tischner, Myślenie w żywiole piękna (Kraków: Wydawnictwo Znak, 2004), 196.

${ }^{56}$ Tischner, "Idea osoby," 161.

${ }^{57}$ Tischner, "Dążenie do ontologizacji," 211.
} 
An ethical deed of a man is a true creativity, true constructing. A man builds himself. A man builds the world. This way he brings values into life. Thanks to him, what is corporeal and material becomes spiritual, precious, valuable. ${ }^{58}$

\section{CONCLUSIONS}

The analysis of Mann's and Bramblitt's artistic development, their accomplishments and struggle with the matter and their own limitations puts forward many questions about the potential of human mind. The examples of both painters clearly show that an efficient eyesight is not a necessary precondition for performing visual arts, neither does its loss mean its annihilation. If the blind painters did not get any satisfaction from their work, they would give it up! Completion of artistic goals, controlling the creation process, the ability to express emotions and meanings comprehensible and attractive for a viewer is a dream of any artist, no matter how competent or disabled. Though Mann's and Bramblitt's examples go beyond the definition of art therapy suggested by Elżbieta Paradowska, their lives nevertheless validate the most, if not all, therapeutic functions. Art opens a new world where disability is unimportant. Art helps people stand above their disabilities, cross them over, become free, able and valued. The act of creating, she says, provokes the feeling of causality. This, in turn, fosters fulfillment and self-expression along with boosting self-confidence and self-esteem. ${ }^{59}$

Tischner observes that everybody is exposed to some kind of ethical experience which occurs at the moment of an encounter with another man alike and realizing his likeness and similarity. We are all the same, Tischner seems to postulate. ${ }^{60}$ As Bramblitt observes, the more he paints, the more convinced he is that a difference between a sighted and a sightless painter is very thin. Art, he says, comes from our minds and hearts, and in no way is it restricted to the field of vision. ${ }^{61}$

In his life-long study on the axiomatic values, Tischner's views on beauty and truth crystallize, yet remain fundamentally consistent. As Aleksander Bobko sums up, Tischner's "thinking by the value" ends up in aesthetic rendition of the truth about the man. To live truly, to be truly oneself eventually means to live in

\footnotetext{
58 Józef Tischner, "Etyka wartości i nadziei," in Józef Tischner, O człowieku. Wybór pism filozoficznych (Wrocław-Warszawa-Kraków: Zakład Narodowy im. Ossolińskich, 2003), 175.

${ }^{59}$ Paradowska cites the definition of art therapy after Ewelina J. Konieczna: it is "a spontaneous art of the ill persons subjected to therapists' assistance or a creative and artistic activity undertaken in a therapeutic situation by the persons previously inactive in the artistic domain." Elżbieta Paradowska, "Mówiąc językiem sztuki (O warsztatach arteterapuetycznych dla dorosłych osób głuchoniewidomych)," Szkoła Specjalna, no. 4 (2004): 304, 307 after: Ewelina J. Konieczna, Arteterapia w teorii i praktyce (Kraków: Oficyna Wydawnicza Impuls, 2004).

${ }^{60}$ Tischner, "Etyka wartości," 169.

${ }^{61}$ Bramblitt, and Tate, 193.
} 
a beautiful way, that is to render one's life into a piece of art. ${ }^{62}$ Tischner himself says that a man welcomes the beauty as a value when it presents itself as his goodness, and for the same reason the man opens up to the truth. ${ }^{63}$ By all means, beauty, truth and goodness do not stand in a conflict, but in a powerful convergence. This claim proves true for Mann and Bramblitt. It must be also true for many other disabled artists making their way through the world and a handful of them officially registered as professional artists. ${ }^{64}$ And although disabled persons' art rarely achieves the status of professional achievements high in value and demand, Mann's and Bramblitt's tremendous success proves that art is a cure which helps both the artist and the viewer. Human drama features some colors after all.

\section{BIBLIOGRAPHY}

Adams, Tim. "Sargy Mann: the Blind Painter of Peckham." The Guardian (November 21, 2010). https://www.theguardian.com/artanddesign/2010/nov/21/sargy-mann-blind-painter-tim-adams.

"Blind Painter Sargy Mann: Painting with Inner Vision." YouTube video, 4:29. Posted by BBC News, October 26, 2014, https://www.youtube.com/watch?v=x9vHwCIaSwM.

Bramblitt, John, and Lindsey Tate. Shouting in the Dark. My Journey Back to the Light. Guilford, Connecticut: Lyons Press, 2012.

Darwent, Charles. "Sargy Mann Obituary." The Guardian (April 16, 2015). https://www.theguardian.com/artanddesign/2015/apr/16/sargy-mann.

"The Guardian View on Disability and the Arts; Time for Change. Editorial," The Guardian (December 3, 2018), https://www.theguardian.com/commentisfree/2018/dec/03/the-guardianview-on-disability-and-the-arts-time-for-change.

Heidegger, Martin. What is Called Thinking? Translated by Fred D. Wieck and J. Glenn Gray. New York-Evanston-London: Harper \& Row Publishers, 1968.

Konieczna, Ewelina J. Arteterapia w teorii i praktyce. Kraków: Oficyna Wydawnicza Impuls, 2004.

Kot, Dobrosław. "Przyswoić sobie siebie i ziemię. Uwagi o Tischnerowskiej filozofii dramatu." Ethos, no. 1-2 (2007): 253-266.

Łukasiak, Elżbieta, and Elżbieta Oleksiak. "Osoby niewidome i niedowidzące.” In: Zbiorczy raport $z$ diagnozy świadczonych ustug z zakresu rehabilitacji społecznej dla osób

${ }^{62}$ Aleksander Bobko, "Wstęp," in: Józef Tischner, O człowieku. Wybór pism filozoficznych (Wrocław-Warszawa-Kraków: Zakład Narodowy im. Ossolińskich, 2003), XXV.

${ }^{63}$ Józef Tischner, "W horyzoncie dobra i zła," in: Józef Tischner, Myślenie w żywiole piękna (Kraków: Wydawnictwo Znak, 2004), 286.

${ }^{64}$ The group of disabled working artists reaches 9\% in UK; in Poland in 2009-10 18\% of all blind people registered by PZN were professionally active; only $0,2-2 \%$ of them include artists among other professions. "The Guardian view on disability and the arts; time for change. Editorial," The Guardian (December 3, 2018), https://www.theguardian.com/commentisfree/2018/dec/03/theguardian-view-on-disability-and-the-arts-time-for-change; Elżbieta Łukasiak, and Elżbieta Oleksiak, "Osoby niewidome i niedowidzące," in Zbiorczy raport z diagnozy świadczonych ustug $z$ zakresu rehabilitacji spotecznej dla osób niepetnosprawnych $w$ Polsce, ed. Beata Maria Kaczmarek (Warszawa: Koalicja na Rzecz Osób z Nepełnsprawnością, Fundacja im. Stefana Batorego, Ministerstwo Pracy i Polityki Społecznej, 2011), http://www.koalicjaon.org.pl/photo/ File/projekt_standardy/raport_zbiorczy_z_diagnozy_swiadczonych_uslug_rehabilitacyjnych.pdf. 
niepetnosprawnych $w$ Polsce. Edited by Beata Maria Kaczmarek. Warszawa: Koalicja na Rzecz Osób z Nepełnsprawnością, Fundacja im. Stefana Batorego, Ministerstwo Pracy i Polityki Społecznej, 2011.

Mann, Sargy. "Sargy Mann: How a Blind Painter Sees." BBC News Magazine (14 June 2015), https://www.bbc.com/news/magazine-33109430.

Nietzsche, Friedrich. Beyond Good and Evil. Translated by Marion Faber. New York-Oxford: Oxford University Press, 2008.

- The Birth of Tragedy out of the Spirit of Music. Translated by Shaun Whiteside. London: Penguin Books, 1993.

Sargy Mann. Documentary film directed by Peter Mann, 38:30, 2006, United Kingdom. Produced by Peter Mann Pictures. https://www.youtube.com/watch?v=8x6c2W_nGNA.

Tischner, Józef. Krótki przewodnik po życiu. Kraków: Wydawnictwo Znak, 2017.

- Myślenie w żywiole piękna. Kraków: Wydawnictwo Znak, 2004.

- O człowieku. Wybór pism filozoficznych. Wrocław-Warszawa-Kraków: Zakład Narodowy im. Ossolińskich, 2003.

- Spór o istnienie człowieka. Kraków: Wydawnictwo Znak, 1998.

Swiat ludzkiej nadziei. Wybór szkiców filozoficznych 1966-1975. Kraków: Wydawnictwo Znak, 1992. 